\title{
Towards a Stylistic Model for Analysing Anglophone African Literatures: Preliminary Epistemological Considerations and a Case Study
}

\author{
Daria Tunca \\ University of Liège, Belgium
}

\section{Introduction}

Debates around the question of language in African literatures have been ubiquitous ever since the Nigerian critic Obiajunwa Wali famously declared, in a 1963 article published in the journal Transition, that African authors writing in European languages "[we]re merely pursuing a dead end, which c[ould] only lead to sterility, uncreativity, and frustration" (1997/1963: 333). Wali's statement had a two-pronged effect: on the one hand, his declaration unsurprisingly sparked a chain reaction about the issue of language choice in African writing, ${ }^{1}$ a question that has to this day remained at the centre of heated arguments; on the other hand, his provocative assertion brought to the fore considerations about the formal specificities of African literatures in European languages. In the sphere of literary criticism, the latter development translated into an increasing interest in linguistically-oriented studies of Anglophone African works, as many commentators attempted to identify the stylistic qualities of novels, poems, and plays written in the former colonial language. However, despite this upsurge in scholarship, no clearly defined method enabling one to perform a comprehensive linguistic examination of African literatures in English has emerged to date.

The reasons behind this paradox will be explored in the first part of this essay. I shall attempt to demonstrate that the causes of the critics' inability to design an extensive model for stylistic analysis are chiefly epistemological. Put differently, I would like to suggest that the aforementioned methodological limitations originate in scholars' disagreement, or even indecisiveness, over the source and methods of knowledge that should be used to carry out linguistic analyses of African literatures in English. Part of my argument is that these epistemological hurdles have presented themselves on at least two levels: that of the origin of

\footnotetext{
${ }^{1}$ The first of these responses were also published in Transition, as rejoinders to Wali's piece - See e.g. the texts by Ezekiel (Es’kia) Mphahlele (1997/1963), Wole Soyinka (1997/1963) and Gerald Moore (1997/1963) in issue 11. The entire exchange of opinions that appeared in the journal was later republished in issue 75/76.
} 
Published in: Style in African Literature: Essays on Literary Stylistics and Narrative Styles, ed. by J.K.S. Makokha, Ogone John Obiero \& Russell West-Pavlov (Amsterdam \& New York: Rodopi, 2012), pp. 31-57.

Status: Postprint (Author's version)

the object of investigation, and that of the discipline of stylistics itself. ${ }^{2}$ While the difficulties encountered on these two planes have been chronologically coterminous, they will be considered separately here - not only for reasons of clarity, but also because these obstacles have been encountered in two distinct movements of linguistic research into African literatures: one focusing on the culturally-specific aspects of texts, and the other attempting a less context-dependent examination of literary pieces.

These two parallel movements have hardly interacted over the years, even though, I shall contend, a thorough understanding of the linguistic makeup of Anglophone African literatures would demand that these lines of research be confronted, and any possible synergies between them actively promoted. This type of conceptual development can evidently not be achieved in a single essay; yet, I shall, however modestly, attempt to lay the basis for a reflection on such an integrative model. I shall do this with particular reference to Nigerian fiction, and more specifically by proposing a brief examination of Chimamanda Ngozi Adichie's novel Purple Hibiscus (2003). Ultimately, I hope to show that only the combined understanding of culturally-specific and context-independent items can lead to a detailed interpretation of Adichie’s book based on its linguistic features.

Before doing this, I propose to provide an outline of the different factors that have shaped - or hindered the development of - linguistic analyses of Anglophone African literatures over the years. Indeed, grasping the historical ramifications of what is often referred to as the "language debate" requires that the stakes and complexities of the initial controversy be fully understood.

\section{Historical background: the language debate and linguistic studies of African literatures}

Only the forgetful reader will need to be reminded that among the most notable responses to Wali's controversial statement were those formulated by the critic's compatriot, the writer Chinua Achebe, and, two decades later, by the Kenyan author Ngugi wa Thiong'o. Achebe, disagreeing with Wali, argued that English, the former colonial language in Nigeria, should not be rejected on the sole basis of its being "part of a package deal which included many other items of doubtful value and the positive atrocity of racial arrogance and prejudice" (1975/1965: 58). In an often quoted passage, Achebe further expressed the conviction that, even though his mother tongue was Igbo, he felt that "a new English, still in full communion with its ancestral home but altered to suit its new African surroundings" would "be able to

\footnotetext{
${ }^{2}$ In this article, stylistics will be understood in the broad sense of "method of interpretation in which primary of place is assigned to language" (Simpson 2004: 2).
} 
Published in: Style in African Literature: Essays on Literary Stylistics and Narrative Styles, ed. by J.K.S. Makokha, Ogone John Obiero \& Russell West-Pavlov (Amsterdam \& New York: Rodopi, 2012), pp. 31-57.

Status: Postprint (Author's version)

carry the weight of [his] African experience” (1975/1965: 62). Ngugi, on the other hand, followed in Wali's footsteps by identifying the former colonial languages as "means of spiritual subjugation” in Africa (1986: 9), and unambiguously stating that Europhone writing "reinforce[d] the spirit of neo-colonialism that [had] succeeded independence" (1986: 26). Both Achebe and Ngugi went beyond these theoretical statements, and endeavoured to put their convictions into practice: Achebe developed a writing style which, although grammatically aligned with standard English, mirrored the semantics of Igbo by using idioms and proverbs translated from the novelist's mother tongue, while Ngugi abandoned the use of the language that he considered a tool of neo-colonial oppression in his creative work, and chose to write novels and plays in his native Gikuyu - while, however, continuing to write essays and give lectures in English.

Achebe's and Ngugi's opinions, which embody the diverging responses to Wali's article, are part of a series of reflections which, since the 1960s, have endeavoured to evaluate the appropriateness of using European languages in African literatures. These considerations have ranged from theoretical assessments of the writers' and critics' positions - appraisals that have mostly relied on political and cultural arguments - to close analyses of literary pieces. Many of the latter studies have been fundamentally shaped by the debate sparked off by Wali. Indeed, as mentioned earlier, the sheer number of these analyses can partly be put down to the interest in language provoked by the Transition controversy; even more importantly perhaps, the fact that most of these linguistic studies set out to examine the specifically “African” elements present in literary pieces can be understood as an implicit denial of Wali's claim that Europhone African literatures - and their critics - mindlessly enforced standards dictated by Western academia (Wali 1997/1963: 332).

Within the body of research focusing on the culturally-specific items found in African writings, a further distinction needs to be drawn between two types of analyses. Some studies, undertaken by literary scholars, rather successfully assessed the narrative significance of tropes such as proverbs or folktales, but without providing in-depth linguistic examinations of these elements (e.g. Griffiths 1971; Obiechina 1993). Other investigations, more accomplished on the technical level, focused on the influences of local African languages on the prose or verse of writers from the Sub-Saharan part of the continent. Because the thorough analysis of specific semantic and syntactic features required the mastering of sophisticated linguistic tools, these enquiries were mostly conducted by linguists (e.g. Bamiro 2006; Igboanusi 2001). No doubt as a consequence of their authors' area of expertise, these works tended to privilege the minute technical description of selected passages from novels over 
Published in: Style in African Literature: Essays on Literary Stylistics and Narrative Styles, ed. by J.K.S. Makokha, Ogone John Obiero \& Russell West-Pavlov (Amsterdam \& New York: Rodopi, 2012), pp. 31-57.

Status: Postprint (Author's version)

their narrative interpretation, leaving some literary critics with the feeling that the formal analysis of African literatures did not provide a decisive contribution to the aesthetic understanding of these texts. More disturbingly perhaps, some of these linguistic examinations tended to consider literary extracts as they would any other real-life sample, thereby bestowing on them an aura of authenticity that ignored the crucial input of writers' creativity. ${ }^{3}$ In some cases, representatives of this approach only narrowly avoided succumbing to the linguistic equivalent of what Henry Louis Gates has called the "anthropology fallacy" (1984: 5), which consists in ignoring the aesthetic value of literary texts and considering them as sociological documentaries or anthropological treatises.

However, among the studies that have concentrated on the culturally-specific features of literary texts, one work has managed to perform rigorous linguistic analyses without ever losing sight of how a text's formal traits could bear relevance to its poetic strategies. The book in question, Chantal Zabus' The African Palimpsest: Indigenization of Language in the West African Europhone Novel (1991), was arguably groundbreaking at the time of its first publication, and has remained highly relevant since. ${ }^{4}$ The study's long-lasting pertinence can be ascribed to its impressive scope - it tackles a range of linguistic characteristics of West African literatures in both French and English - but also to its methodological incisiveness. To give but one example, Zabus did not take at face-value that the passages in pidgin in Anglophone Nigerian novels perfectly mirrored the language as it was spoken in reality, and she proceeded to analyse such extracts in detail. She convincingly claimed that most of the literary occurrences of the linguistic code only qualified as "pseudo-pidgin,” since many of these renderings displayed numerous influences of English not typically associated with "reallife” pidgin. Importantly, Zabus went beyond these strictly formal conclusions and, rather than dismiss the fabricated language on essentialist grounds, she attempted to account for its presence and examine its functions within Nigerian fiction.

Zabus covered so much methodological ground that few of those doing linguisticoriented research in her wake succeeded in improving on her findings. Admittedly, some scholars writing during the 1990s managed to gain insight into specific literary texts (see for instance some of the essays contained in Epstein and Kole's collection The Language of African Literature, 1998). However, even as the literary value of cross-cultural Europhone

\footnotetext{
${ }^{3}$ I do not mean to suggest that theories usually applied to real-life language cannot be used when examining literary samples, but rather that a prescriptive use of this type of critical framework may not be entirely appropriate in such situations. Moreover, I find it slightly problematic that literary samples should be used to conduct research into non-literary linguistic topics such as the semantics of Nigerian English.

${ }^{4}$ This contemporary relevance seems to be evidenced by the publication of a second enlarged edition of the book in 2007.
} 
Published in: Style in African Literature: Essays on Literary Stylistics and Narrative Styles, ed. by J.K.S. Makokha, Ogone John Obiero \& Russell West-Pavlov (Amsterdam \& New York: Rodopi, 2012), pp. 31-57.

Status: Postprint (Author's version)

African literatures had been convincingly established - and thereby the "dead end" scenario predicted by Wali once and for all disproved - critics were, ironically enough, reaching another dead end. Indeed, research into the culturally-specific features of African writing focussed - almost by definition - on language as a cultural (or, in some cases, social) signifier in given contexts, thus completely disregarding linguistic traits that the literatures might have in common with traditions from other continents. As African literary texts began to be consistently considered in terms of their linguistic "Otherness," language-oriented enquiries ran the risk of losing their critical potency.

The scant attention given to the literatures' possibly universal qualities can partly be explained by the pervasive influence of the language debate. Nevertheless, one might also suggest - perhaps slightly provocatively - that it also finds its origin in another series of incidents that defined the critical climate of the last three or four decades of the twentieth century. Indeed, while Wali had indicted both Europhone African writers "and their Western midwives” (1997/1963: 333), others had denounced some Western critics’ inclination to make sweeping statements about African literatures in the name of universality. There was undoubtedly some validity to this complaint, for certain European and American commentators alleged to uncover “"universal truths"” which, in Kadiatu Kanneh's felicitous words, “act[ed] merely as euphemisms for European [or, more broadly, Western] truths" (1997: 81). This tendency was forcefully denounced in the 1970s by the Ghanaian writer Ayi Kwei Armah, who even gave it a name, "larsony," after the literary critic Charles Larson who, in his eyes, was guilty of peremptorily perpetuating cliché-ridden representations of Africa. The term coined by Armah was later used by Chinweizu, Jemie and Madubuike in their Towards the Decolonization of African Literature (1983), in which they condemned Larson's and others' wholesale universalism, and explicitly pleaded in favour of a system of aesthetic evaluation based on "authentic" African paradigms.

Chinweizu et al.'s Afrocentrist reasoning was not unanimously approved. It co-existed with other popular positions in the area of Black and African studies, such as that of Henry Louis Gates, who emphasized the "complexity" of Europhone Black and African texts, a result of their "double heritage” (1984: 4). In the field of traditional literary criticism, many scholars implicitly sided with Gates, in that they continued to analyse African literatures using a mixture of theories originally arising out of Western contexts (the poststructuralist works of Michel Foucault and Jacques Derrida come to mind) and other models that had been more specifically developed to address the distinctness of postcolonial African situations. In the contention-prone domain of linguistic studies of African literatures, on the other hand, many 
Published in: Style in African Literature: Essays on Literary Stylistics and Narrative Styles, ed. by J.K.S. Makokha, Ogone John Obiero \& Russell West-Pavlov (Amsterdam \& New York: Rodopi, 2012), pp. 31-57.

Status: Postprint (Author's version)

Europeans and Americans seemed intent on not becoming the next Charles Larson. Thus, while the warnings by Armah and Chinweizu et al. had the positive effect of urging academics to carry out contextualized stylistic research into African literatures, it may also have been one of the factors that discouraged many from undertaking linguistic examinations based on Western theoretical models. As a result, the linguistic criticism of African literatures remained largely - though not totally - impervious to methods of systemic-functional, cognitive and transformative-generative inspiration privileged by Western stylisticians over the same decades.

Nevertheless, a few scholars did make bold attempts to apply Western stylistic models to African objects of inquiry. ${ }^{5}$ It might not be coincidental, though this is only a conjecture, that most of these studies were conducted by African scholars - who, one may assume, ran a lower risk of being labelled paternalistic in applying "white” models to works written by black authors. ${ }^{6}$ Crucially, most of these experimental ventures had a limited impact on the field of African studies. This can be explained by most of the analyses' modest circulation, but also by some of their weaknesses - flaws which had been inherited from the Western stylistic tradition. Indeed, if the field of African literary criticism had had to contend with its practitioners' disagreement over criteria of aesthetic evaluation, the domain of stylistics had long hosted its own epistemological battles too.

In the field of Western stylistics (a domain that concentrated on the study of European and American texts), the discordance among experts did not concern the cultural origin of the analytical models to be applied, but the very relevance of certain methodological choices. The most notable criticism of the discipline came from Stanley E. Fish who, in a well-known article somewhat humorously entitled "What Is Stylistics and Why Are They Saying Such Terrible Things about It?” (1996/1980), condemned what he perceived as the circularity and/or arbitrariness of stylistic methods, be they computer-based corpus analyses, experiments performed by transformative-generative grammarians or interpretations reached through systemic-functional frameworks. Whether or not one agrees with the tone of Fish's reproachful demonstrations of inefficiency, one must acknowledge that he put his finger on one of the problems at the very core of the discipline, namely that far too many of its representatives either contented themselves with providing descriptive accounts of their

\footnotetext{
${ }^{5}$ A few examples include Adejare, 1992, and Akekue, 1992 (both inspired by systemic functional grammar), Adegbija, 1998 (speech-act theory), Essien, 2000 (discourse analysis) and Winters, 1981 (transformativegenerative grammar and quantitative stylistics).

${ }^{6}$ Needless to say, I do not claim to have had access to the entire body of literature in which Western linguistic models are used to analyse African works; this statement is merely based on observation.
} 
Published in: Style in African Literature: Essays on Literary Stylistics and Narrative Styles, ed. by J.K.S. Makokha, Ogone John Obiero \& Russell West-Pavlov (Amsterdam \& New York: Rodopi, 2012), pp. 31-57.

Status: Postprint (Author's version)

objects of study ${ }^{7}$ or took an interpretative leap but masked their shaky landing with a sophisticated technical apparatus (Fish 1996/1980: 96).

In the field of Anglophone African literatures, the small group of critics who chose the route of Western stylistic methods was by far dominated by scholars with a leaning towards descriptiveness. Understandably, then, when Emmanuel Ngara published his Marxist-oriented Stylistic Criticism and the African Novel in 1982, he attempted to distance himself from those who listed the linguistic features of literary works but did little else. To this effect, he introduced a distinction between the practitioners of "stylistics" and those of "stylistic criticism":

the stylistician ... uses the principles of general linguistics to single out the distinctive features of a variety of [sic] the idiosyncracies of an author. He uses the principles of general linguistics to identity the features of language which are restricted to particular social contexts, and to account for the reasons why such features are used and when and where they are used. ... The stylistic critic ... certainly must use the analytic tools of the linguist and stylistician .... But more than that he must relate his analysis of linguistic features to considerations of content value and aesthetic quality in art. (1982: 11-12)

The contrast proposed by Ngara is helpful (if somewhat prescriptive), ${ }^{8}$ but it did not gain wide currency. Importantly, however, the distinction that he makes here embodies his willingness to develop a rigorous critical framework for the linguistic study of African writing, a challenge to which he attempts to respond in the stimulating introduction to his study. Aware of the complex historical heritage of African literatures, Ngara advises that "the African critic should search for African solutions in criticism, or should search for those solutions which, though not specifically African, will do justice to African works of art” (1982: 6). ${ }^{9}$ As is made clear in the book, Ngara is above all claiming his allegiance to Marxism when writing these lines, but he also argues in favour of using terminology developed in systemic-functional

\footnotetext{
${ }^{7}$ Significantly, this is the very same flaw as that which can be identified in certain studies of culturally-specific linguistic aspects of African literatures. This suggests that the weakness is, unsurprisingly, one linked to stylistic methodology and not dependent on the object of research.

${ }^{8}$ This reservation is motivated by the presence of the modal auxiliary "must," used twice in this short passage and repeatedly featured throughout Ngara's writings (see also his Ideology and Form in African Poetry, 1990). Though I have not studied this in detail and have not been able to locate specific critical sources, I would hazard that such a recurrence might be a characteristic trait of what could be called Marxist writing styles.

${ }^{9}$ Even if the phrase "the African critic" refers to "the critic from Africa" in this particular context, Ngara does not advocate that the study of African literatures should be the prerogative of Africans alone. As he writes a few paragraphs later, "If a European critic knows Africa well, is honest and unbiased, and is a competent critic using sound critical standards relevant to African art, there is no reason why his pronouncements on African literature should not be as valid as those of informed African critics” (1982: 8).
} 
Published in: Style in African Literature: Essays on Literary Stylistics and Narrative Styles, ed. by J.K.S. Makokha, Ogone John Obiero \& Russell West-Pavlov (Amsterdam \& New York: Rodopi, 2012), pp. 31-57.

Status: Postprint (Author's version)

models, for example.

Unfortunately, once put into practice, Ngara's ideas fall short of fulfilling their promise. Although the author skilfully avoids the pitfalls of descriptivism and arbitrariness, his study does not offer the expected methodological breakthrough. His analyses, while often insightful, rest on techniques more akin to close reading than modern stylistic analysis. Yet, the importance of Ngara's contribution to the field of “African stylistics" should not be underestimated. First of all, even though the language-related examinations that he proposes do not provide the technical basis for a literary-linguistic model, such close readings offer an invaluable prelude to potentially more thorough stylistic analyses. In the case study that will shortly follow, I shall in a somewhat similar vein be arguing that sociolinguistic theory, while not necessarily throwing light on components of style in the narrow sense of the term, can be an effective tool in exploring the worldviews of characters. The results thereby obtained can, in turn, act as helpful stepping stones to more precise investigations into semantic and syntactic features.

Secondly, the value of Ngara's attempt can only be fully appreciated when resituating his study in its historical context. One should indeed remember that, at the time the author was publishing his book, some of the most influential works in linguistics and stylistics had only just been released - Geoffrey Leech and Mick Short's Style in Fiction (2007/1981) and George Lakoff and Mark Johnson’s Metaphors We Live By (1980) had come out respectively one and two years prior to Ngara's study and, understandably, they do not feature in his bibliography. Other major works, such as Roger Fowler's Linguistic Criticism (1996/1986), were still several years away. Despite its shortcomings, then, Stylistic Criticism and the African Novel remains a landmark in the stylistics of African literatures. Not only did the author emphasize the centrality of linking the linguistic features of a literary work to its content - as indicated in the subtitle of the book, A Study of the Language, Art and Content of African Fiction - but he also insisted on the importance of creating of a model that might help one to examine African literatures from different formal angles, using critical perspectives that had emerged on the African continent and elsewhere. It may be regretted that Ngara's pioneering efforts were not emulated - in the words of Charles E. Nnolim, "Ngara [...] dangled an apple, but there were no takers” (2000: 14). Until now, that is. 
Published in: Style in African Literature: Essays on Literary Stylistics and Narrative Styles, ed. by J.K.S. Makokha, Ogone John Obiero \& Russell West-Pavlov (Amsterdam \& New York: Rodopi, 2012), pp. 31-57.

Status: Postprint (Author's version)

\section{Towards a Stylistic Model for Analysing Anglophone African Literatures? Methodological Clarifications and a Case Study}

Since Emmanuel Ngara published his Stylistic Criticism and the African Novel, much has happened in the field of Western linguistics and stylistics: the application of systemicfunctional models to (mostly non-literary) texts has been fine-tuned by critical discourse analysts; George Lakoff has expanded his theory of conventional metaphor to include creative avatars of the trope (see his work in collaboration with Mark Turner, 1989); and cognitive stylistics, though still an emerging field, has been moving in promising directions during the past few years (e.g. Semino and Culpeper 2002; Stockwell 2002). Added to these developments, significant progress has been made in culturally-specific linguistic examinations of African literatures (see Zabus 2007/1991, mentioned above), as well as in Africa-oriented sociolinguistics, creolistics and the study of varieties of English. In short, today's stylisticians - or stylistic critics, to echo Ngara - have the necessary critical basis at their disposal to design a model to analyse Anglophone African literatures. But three challenges remain: first, that of adapting some of the abovementioned Western approaches to African writing; second, that of using all theories in a complementary way so as to lead to novel literary interpretations; and third, that of going even beyond the first two steps and integrating separate theories into a single analytical paradigm. The third point, which constitutes by far the most exacting task, is too complex to be resolved here, but possible lines of research will be evoked in the conclusion to this essay. The first two undertakings, by contrast, will be tentatively tackled in what follows in the hope of offering a preliminary demonstration of how these ideas might be put into practice.

Before proceeding to do this, however, a final clarification is needed regarding my methodological approach. Like linguist Katie Wales, I consider the ultimate aim of the stylistic enterprise to be the "ground[ing of] intuitions or hypotheses in a rigorous, methodical, and explicit textual basis" (Wales 2006: 213). If the effort to "ground intuitions" is one of the main goals of stylistic analysis, this does not mean, at least in my view, that the linguistic study of fiction is more objective than conventional literary criticism. What might at first seem as a disavowal of the approach I intend to adopt is in fact a simple recognition that, on the one hand, the aforementioned "intuitions" are as important as the "grounding" that follows them and that, on the other, no single science is founded on "pure" objectivity. ${ }^{10}$ The

\footnotetext{
${ }^{10}$ As Lakoff puts it, "there is no such thing as a neutral way to understand things" (1987: 300). Objectivity, in the sense defined by Lakoff, is not the "God's eye point of view" of the objectivists, but it rather resides in the ability to recognize that one has a specific point of view, to understand its nature, and to assess a situation from
} 
Published in: Style in African Literature: Essays on Literary Stylistics and Narrative Styles, ed. by J.K.S. Makokha, Ogone John Obiero \& Russell West-Pavlov (Amsterdam \& New York: Rodopi, 2012), pp. 31-57.

Status: Postprint (Author's version)

simple fact of choosing a novel to examine and of establishing a theoretical framework to analyse the said text can be considered a subjective - albeit not necessarily uninformed - act.

Even if I acknowledged above that Fish had identified some of the problems regularly encountered in stylistic studies of literature, namely their circularity or arbitrariness, I believe that he is mistaken in declaring that "description performed at the direction of a preformulated literary hunch" entails that one "pre-decides [meaning] arbitrarily” (Fish 1996/1980: 111). Being "guided by [a] hunch”, as Roger Fowler puts it (1996/1986: 9), ${ }^{11}$ does not mean that one eventually demonstrates what one had in mind at the onset of the procedure. In this regard, Spitzer's "philological circle” provides an interesting conceptualization of the process of stylistic analysis. The notion is here explained by Leech and Short:

Spitzer argued that the task of linguistic-literary explanation proceeded by the movement to and fro from linguistic details to the literary 'centre' of a work or a writer's art. There is a cyclic motion whereby linguistic observation stimulates or modifies literary insight, and whereby literary insight in its turn stimulates further linguistic observation. This motion is something like the cycle of theory formulation and theory testing which underlies scientific method. (2007/1981: 12)

The movement described here, although circular, is very different from the circularity observed by Fish. One of the most important ideas put forward by Spitzer is that literary assessments and foci of linguistic examinations evolve, in dialectical fashion, as the critic proceeds. Equally important is the fact that the modifications made to the initial hypotheses are based on observation. In other words, the development of the process of interpretation rests on motivation, understood here in the sense of intellectual justification. It is with the concept of motivated choice - rather than that of pure objectivity - that I shall try to operate in the following analysis. This approach naturally involves the use of certain theories rather than others, and the selection of particular passages from Chimamanda Ngozi Adichie's Purple Hibiscus, a novel which I shall first of all briefly summarize.

Purple Hibiscus, published in 2003, is told through the eyes of an adolescent narrator, Kambili Achike, and offers a sensitive portrayal of an Igbo family living in the South-Eastern region of Nigeria in the late twentieth century. Kambili's father, Eugene, is a respected businessman and a human rights champion, but also an extremist Catholic who regularly beats 
Published in: Style in African Literature: Essays on Literary Stylistics and Narrative Styles, ed. by J.K.S. Makokha, Ogone John Obiero \& Russell West-Pavlov (Amsterdam \& New York: Rodopi, 2012), pp. 31-57.

Status: Postprint (Author's version)

his wife Beatrice and his children, Kambili and her brother Jaja, in the name of religious propriety. Significantly, he also refuses to have any contact with his own father, a follower of traditional Igbo religion, and forbids his children to spend more than a few minutes per year with the old man. In the course of the story, Kambili and Jaja are allowed to stay with Eugene's more liberal sister Ifeoma and her three children, to all of whom they gradually become closer. Thanks to their aunt, the Achike children also develop a relationship with their grandfather, the very man Eugene despises. In contact with these moderate Catholic family members, Kambili and Jaja, who had been infused with Eugene’s fanatical precepts since childhood, learn to question their father's uncompromising views, each in their own way.

This short summary suffices to establish that Purple Hibiscus explores themes such as traditional and Christian religion, cultural and intergenerational conflicts. While these subject matters that have often been developed in African literatures - starting with the writings of Adichie's favourite author, her illustrious compatriot Chinua Achebe - the originality of the young writer's novel lies in its subtle depiction of its protagonists' psychological evolution. Crucially, a thorough understanding of both the socio-cultural and emotional factors contributing to the delineation of the characters is needed to reach an interpretation that is reflective of the book's manifold stylistic strategies. Put differently, any linguistic analysis aiming at a global understanding of the narrative needs to consider these two different planes, which require the use of different methods of analysis. In what follows, I shall briefly attempt to put this idea into practice, and demonstrate how two theories - one of sociolinguistic inspiration, the other with a systemic-functional basis - can help to uncover some of the mechanics of character interaction and evolution in the book.

Considering the contemporary African setting of the story and the social status of the characters, it should come as no surprise to the initiated reader that codeswitching - the alternate use of two or more languages within a conversation or even within a single utterance - features as a major technique in Purple Hibiscus. Many of the characters indeed switch between English and Igbo, a change that not only reflects the dynamics of particular conversations, but also more broadly mirrors the characters' attitudes to certain social conventions. This feature may not always have a substantial impact on the stylistic level for, as will be illustrated in a moment, the author may choose to render words uttered in Igbo fully in English, sometimes with a mention of the language in which the character is speaking. Nevertheless, understanding the motivations behind the protagonists' choice of language offers revealing insight into their personalities; in this sense, this language-related element occupies a central position in the author's strategy of characterization and deserves close 
Published in: Style in African Literature: Essays on Literary Stylistics and Narrative Styles, ed. by J.K.S. Makokha, Ogone John Obiero \& Russell West-Pavlov (Amsterdam \& New York: Rodopi, 2012), pp. 31-57.

Status: Postprint (Author's version)

attention in a linguistic analysis of the novel. ${ }^{12}$

This assertion should become clearer when examining the following extract, in which Kambili, Jaja, Ifeoma and her children, Amaka, Obiora and Chima, are on their way to a traditional festival in Abagana. They are joined by the grandfather, referred to as PapaNnukwu:

“Papa-Nnukwu, good afternoon, sir,” Jaja and I greeted.

"Kambili, Jaja. I see you again before you go back to the city? Ehye, it is a sign that I am going soon to meet the ancestors.”

“Nna anyi, are you not tired of predicting your death?” Aunty Ifeoma said, starting the engine. "Let us hear something new!” She called him nna anyi, our father. I wondered if Papa used to call him that and what Papa would call him now if they spoke to each other.

"He likes to talk about dying soon," Amaka said, in amused English. "He thinks that will get us to do things for him,” [sic]

“Dying soon indeed. He'll be here when we are as old as he is now," Obiora said, in equally amused English.

“What are those children saying, gbo, Ifeoma?” Papa-Nnukwu asked. “Are they conspiring to share my gold and many lands? Will they not wait for me to go first?”

"If you had gold and lands, we would have killed you ourselves years ago," Aunty Ifeoma said. (2003: 82)

In this passage, Amaka and Obiora, Kambili and Jaja's cousins, both playfully switch to English so that their grandfather will not understand the remarks jokingly made at his expense. English is repeatedly spoken by Ifeoma and her children in comparable circumstances, because the sole language mastered by the elderly man is a variety of Igbo that has "none of the anglicized inflections" (2003: 64) that the younger speakers have acquired in their speech. Unlike many characters in contemporary African fiction, the children do not

\footnotetext{
${ }^{12}$ The scope and length of the present article being limited, my discussion will merely assess the importance of the characters' choice of language within the narrative. This means that two important author-related areas of investigation will not be addressed here: on the one hand, I shall not attempt to shed light on the reasons behind (and the impact of) the writer's technical choices in her rendering of Igbo and English (a brief overview of the linguistic techniques used by Adichie to render the presence of the two languages is provided in Tunca 2008: 155-158); on the other hand, I shall not pursue the line of enquiry pertaining to how the author's stylistic choices within standard English may contribute to the creation of a distinctive type of "African narration". Both aspects, however, would deserve careful attention.
} 
Published in: Style in African Literature: Essays on Literary Stylistics and Narrative Styles, ed. by J.K.S. Makokha, Ogone John Obiero \& Russell West-Pavlov (Amsterdam \& New York: Rodopi, 2012), pp. 31-57.

Status: Postprint (Author's version)

seem to switch to English to exploit what Carol Myers-Scotton has called the "indexical" qualities of English in Sub-Saharan countries, i.e. the attributes associated with English in certain situations, ${ }^{13}$ but their mastery of the former colonial language is nevertheless an obvious result of their exposure to a Western form of education. The benign domestic episodes in which Papa-Nnukwu is disorientated by his interlocutors' switch to English shows how monolingualism renders speakers of Igbo as vulnerable as the old man himself: those who do not speak English in Nigeria must rely on the goodwill of others to remain in charge of their own fate. ${ }^{14}$

Differences in language come to symbolize cultural and intergenerational discrepancies, as illustrated by the fragile communication between Kambili and her grandfather. During their first meeting in the book, Kambili reports that "sometimes [she] understood him a moment or two after he spoke because his dialect was ancient” (2003: 64). The cultural gulf between Papa-Nnukwu and the girl is aptly represented by the time-lag between the moment he speaks and the moment she understands him. Conversely, Kambili's cousin Amaka attempts to bridge this gap by making consistent efforts to be understood by Papa-Nnukwu. She "hardly pepper[s] her speech with English words" when she addresses him, as the other protagonists “inadvertently d[o]” (2003: 172). Acting consistently with her taste for “culturally conscious” music (2003: 118), she assumes the role of interpreter between traditional society and the younger Christian generations. She also metaphorically fulfils a function as mediator by giving her drawing of Papa-Nnukwu to Kambili - a picture which, significantly, remains unfinished due to his death, as if the spirit of traditionalism could never be fully captured by those who do not partake of it.

The narrative contains other indicators of the characters' approaches to culture. The use of the Igbo and English languages during religious rituals deserves to be mentioned among these revealing elements. Eugene, like the conservative Father Benedict, disapproves of “native songs” (2003: 4) being chanted during Mass. In Ifeoma’s home, on the other hand,

\footnotetext{
${ }^{13}$ English, when used in African contexts, is often regarded as a mark of formality or as signalling the speaker's high educational level and/or socio-economic status (Myers Scotton 1993: 86). The idea of being "marked” is central in Myers-Scotton's model, which "proposes that speakers have a sense of markedness regarding available linguistic codes for any interaction, but choose their codes based on the persona and/or relation with others which they wish to have in place. This markedness has a normative basis within the community, and speakers also know the consequences of making marked or unexpected choices. Because the unmarked choice is 'safer' (i.e. it conveys no surprises because it indexes an expected interpersonal relationship), speakers generally make this choice. But not always. Speakers assess the potential costs and rewards of all alternative choices, and make their decisions, typically unconsciously” (1993: 75).

${ }^{14}$ Extending this interpretation to the political level, one may argue that individuals who do not master English are alienated from the spheres of power in the country. On the possible parallels between the domestic and national spheres in Purple Hibiscus, see e.g. Lopez (2008: 89).
} 
Published in: Style in African Literature: Essays on Literary Stylistics and Narrative Styles, ed. by J.K.S. Makokha, Ogone John Obiero \& Russell West-Pavlov (Amsterdam \& New York: Rodopi, 2012), pp. 31-57.

Status: Postprint (Author's version)

prayers are interspersed with vocal pieces in Igbo, as Kambili discovers to her great displeasure during her first stay with her aunt. In a manner that brings to mind the "Englishlaced Igbo sentences” (2003: 135) of Father Amadi, the liberal young priest with whom Kambili falls in love, Ifeoma and her children alternate between English and Igbo both in casual circumstances and during religious rituals, thereby demonstrating the complementarity of the languages in the articulation of their identities. The family's use of English and their belief in the Christian god shows that they have adopted a language and a faith assigned to them by foreign influences, but the inclusion of Igbo songs into their prayers indicates that, unlike Eugene, they deem their mother tongue worthy of carrying the message of a religion imported from Europe. In other words, neither Igbo nor English, but codeswitching itself is, to use Myers-Scotton's term (1993: 114), the “unmarked” linguistic choice for Ifeoma and her children in the context of prayer. This testifies to an acceptance of the different traditions that have shaped their family; at the same time, however, this linguistic syncretism is infused with a sense of dynamism. Indeed, Aunty Ifeoma's intertwining of European and African traditions seems to evidence a movement towards cross-culturalism, but does not result in a static consensus accepted by all moderate Christians. For instance, Amaka moves beyond her mother's views to initiate a more vigorous movement of resistance against the former colonizer's religion when she refuses to choose a confirmation name, a convention established by the first missionaries who “didn’t think Igbo names were good enough” (2003: 272). In refusing to be renamed, Amaka also defies the pragmatism of Father Amadi, who urges her to “forget if it's right or wrong for now" (2003: 272). Her principled decision seems to stem from a sense of indignation similar to that of the Nigerian poet Niyi Osundare, who deplores that Africa has, ever since its colonization, never been the "name-giver," but always the "named” (2002: 36). Such statements find echoes all over Africa, and particularly in a country such as Nigeria, whose name is reported to be a Latinate evocation of the Niger River, invented by the fiancee of the colony’s first governor (Griswold 2000: 6).

Amaka's unwillingness to comply with the authoritarian demands of the Catholic Church is both religious and political, as her emphatic refusal to take an "English name" (2003: 241, 271; my emphasis) demonstrates. ${ }^{15}$ In addition to her opposition to the reproduction of colonial schemes in Africa, she further advocates a spiritual "Colonization in

\footnotetext{
${ }^{15}$ Amaka's use of the adjective "English" shows that she clearly rejects the colonial undertones of Christianity, since Biblical confirmation names are not "English" per se. Of those mentioned in the novel, Ruth and Michael are of Hebrew origin, while Victor finds its roots in Latin. It should also be mentioned that Christianity was mostly introduced into Igboland by Irish missionaries, not English ones (Adichie, cited in Braunstein, 2005) hence the Catholic rather than Anglican affiliation.
} 
Published in: Style in African Literature: Essays on Literary Stylistics and Narrative Styles, ed. by J.K.S. Makokha, Ogone John Obiero \& Russell West-Pavlov (Amsterdam \& New York: Rodopi, 2012), pp. 31-57.

Status: Postprint (Author's version)

Reverse” ${ }^{16}$ when commenting on Father Amadi’s move to Germany:

The white missionaries brought us their god, ... [w]hich was the same color as them, worshiped in their language and packaged in the boxes they made. Now that we take their god back to them, shouldn't we at least repackage it? (2003: 267)

Amaka's plea in favour of an Africanized form of Christianity, though made in jest, captures one of the novel's fundamental preoccupations, namely the status of religion as a commercial artefact. While the young woman advocates that Africa should appropriate the Christian religion, she is aware that the spiritual cannot be detached from earthly monetary concerns. Her use of the relative pronoun "which" to refer to the Christian god in present-day English, as if he were an item of merchandise "packaged in the boxes they made", evokes consumption, even consumerism - an association that not only echoes the economic interests behind the religious conversion of Africa by the missionaries, but also reflects the commercialism that has become attached to religious practices across Sub-Saharan regions of the continent. Kambili's father repeatedly invokes religion to take the moral high ground, but even his brand of Catholicism does not escape commodification. The attitude of Eugene's priest, Father Benedict, is also symptomatic in this respect: the cleric "seems to measure a man's dedication to God through the gifts he bestows on the church” (Adeaga 2005).

“Repackaging” the Christian faith, as Amaka proposes, is certainly not an activity Eugene engages in. Predictably, his fanatical devotion to the Catholic religion is mirrored in his single-minded reverence for the former colonizer's tongue:

He hardly spoke Igbo, and although Jaja and I spoke it with Mama at home, he did not like us to speak it in public. We had to sound civilized in public, he told us; we had to speak English. (2003: 13)

By associating English with refined westernization and dismissing Igbo as barbaric, Eugene is claiming allegiance to colonial values, but he may also be trying to conceal the brutal side of his personality from the public eye. Indeed, his use of Igbo is almost systematically associated with outbursts of anger. As Kambili reports, Eugene's switch to the language is a "bad sign" (2003: 13). If Igbo may be categorized as Eugene's language of emotion, it is not because, in line with fallacious negritudist views, it is a code spoken by black Africans, but because it is

\footnotetext{
${ }^{16}$ This famous phrase is the title of a poem by Jamaican Louise Bennett (1986/1966).
} 
Published in: Style in African Literature: Essays on Literary Stylistics and Narrative Styles, ed. by J.K.S. Makokha, Ogone John Obiero \& Russell West-Pavlov (Amsterdam \& New York: Rodopi, 2012), pp. 31-57.

Status: Postprint (Author's version)

the character's mother tongue - the language individuals tend to fall back on in emotional situations. Eugene's attempt to suppress his mother tongue is symptomatic of the domination he wants to exert over the African facet of his identity. This obsessive need for control translates into a form of linguistic mimicry: ${ }^{17}$

Papa changed his accent when he spoke, sounding British, just as he did when he spoke to Father Benedict. He was gracious, in the eager-to-please way that he always assumed with the religious, especially with the white religious. (2003: 46)

According to sociolinguistic speech accommodation theory, when "speakers desire their listeners' social approval”, they “use modification of their speech towards the listeners' code as a tactic to get this approval” (Myers-Scotton 1993: 66). Eugene acts in accordance with this prediction. Nevertheless, he is unable to retain his British inflections at all times: he sometimes inadvertently "skip[s] a few words so that half a sentence sound[s] Nigerian and the other half British” (2003: 243). The man has an aversion to Igbo culture so deeply rooted that he even avoids physical contact with traditionalists (starting with his own father) by refusing them access to his house, but he is, for all his efforts, incapable of erasing the remnants of a civilization that the likes of Father Benedict have taught him to despise. Therefore, it is deeply significant that the tongue Eugene dismisses as "uncivilized" should surface most perceptibly when he violently reacts against what he deems to be "heathen" practices. The “mix of Igbo and English” he sputters when "out of control” (2003: 210) reveals a disjointed mind unable to come to terms with the multiple heritages it carries. The violence Eugene inflicts on his family for failing to follow his dogmatic vision of Christianity may in effect be the expression of a sense of fear and hatred towards an inescapable part of his being.

I have discussed two instances of Igbo-English codeswitching in Purple Hibiscus, i.e. the alternation between the languages in Ifeoma's family on the one hand, and Eugene's mixing of the codes on the other. The radically different interpretations I have assigned to these two cases speak in favour of a context-dependent understanding of language use. Languages have no essential qualities when lifted out of their contextual frame. Igbo does not act as a weapon of colonial resistance in Eugene's mouth and, conversely, the English he

\footnotetext{
${ }^{17}$ Eugene's imitation of the former colonizer is devoid of the subversive potential evoked by Homi Bhabha in his essay "Of Mimicry and Man: The Ambivalence of Colonial Discourse," in which the author states that colonial mimicry "is at once resemblance and menace" (1994: 86). As I have argued in another context, the practice of imitation in which some of Adichie's characters engage seems to be symptomatic of a "thoughtless yearning for acceptance” by those whose culture and status these protagonists consider desirable (Tunca, forthcoming).
} 
Published in: Style in African Literature: Essays on Literary Stylistics and Narrative Styles, ed. by J.K.S. Makokha, Ogone John Obiero \& Russell West-Pavlov (Amsterdam \& New York: Rodopi, 2012), pp. 31-57.

Status: Postprint (Author's version)

cherishes can also be used to subvert his extreme convictions. When Jaja, Kambili's brother, openly defies his father by refusing to take communion, he says that "the wafer gives [him] bad breath” (2003: 6). The adolescent deliberately fails to use the Latin word "host,” a term which, according to Eugene, "c[omes] close to capturing the essence, the sacredness, of Christ's body” (2003: 6). Instead, the young man opts for its Anglo-Saxon secular substitute "wafer," which evokes, as Kambili notices, the "chocolate wafer[s], banana wafer[s]” made in one of Eugene's factories (2003: 6). ${ }^{18}$ Jaja challenges his father's authority not only by refusing to obey him and passing unfavourable comments on the sacred host, but also by purposefully utilizing an informal Germanic word where the more formal Latin one would have been expected. He intentionally dissociates himself from his father by producing speech which departs from the register sanctioned by the man - a strategy known as "speech divergence" (Myers-Scotton 1993: 66), which stands at the opposite pole of the "speech convergence” favoured by Eugene when addressing white ecclesiastics. Kambili’s remark concerning the biscuits produced in her father's factories indicates that the word "wafer" does not meet with his approval because it is highly suggestive of commercial exchange in the Achikes' eyes. In this respect, Jaja's comment also indirectly criticizes the commodification of Eugene's sacrosanct religion, and ultimately its hypocrisy. This incident demonstrates that words have more than a referential value in Purple Hibiscus.

A similar argument could be deployed with reference to some of the grammatical structures used in the book. ${ }^{19}$ An analysis of some of these structures, I believe, can act as a crucial supplement to a traditional literary analysis in helping to reveal how some of the underlying themes of the narrative are subtly woven into its form. One such topic, obliquely broached above through the examination of Jaja's transgressive act of speaking, is that of silence - understood in its broad sense as encompassing all that is left unsaid. Indeed, at the chronological onset of the story and throughout most of the book, Kambili is an eerily quiet character who, because of her shyness, finds it difficult to speak aloud. The heroine's muteness has left some reviewers frustrated (see Kaplan 2004; Lalami 2003), but it seems to me that, as Karen Bruce (n.d.) has extensively demonstrated, silence is not merely a "form of oppression” in Purple Hibiscus - in the sense that Kambili's speechlessness can be attributed

\footnotetext{
${ }^{18}$ The etymology of "host" and "wafer" is detailed in the OED. As suggested in Purple Hibiscus, "host" finds its origins in the Latin word for "victim," "sacrifice" (OED), while "wafer," denoting a thin crisp cake, first appeared in Middle English (OED). Both entries indicate that the terms can be used in relation to the Eucharist. On the difference in formality between the Latinate and Germanic registers, see Simpson (1997: 67-68), Verdonk (2002: 64) and Lanham (2003: 160).

${ }^{19} \mathrm{I}$ have addressed this issue extensively in Tunca (2009b). What follows is a condensed version of this piece merely designed to underline the importance of certain grammatical patterns in the novel.
} 
Published in: Style in African Literature: Essays on Literary Stylistics and Narrative Styles, ed. by J.K.S. Makokha, Ogone John Obiero \& Russell West-Pavlov (Amsterdam \& New York: Rodopi, 2012), pp. 31-57.

Status: Postprint (Author's version)

to "her father's abuse" - but it also becomes “a mode of resistance.” The crux of the matter probably lies in the simultaneous presence of these opposite functions in single instances where words are left unspoken. For example, Kambili and her brother Jaja dare not say some things aloud, but the “asusu anya,” or "language of the eyes” (Adichie 2003: 305), allows them to "speak about subjects [of] which [their] father might disapprove” (Bruce, n.d.). Bruce foregrounds another passage revealing this double quality: after Eugene, furious at Jaja's disobedience, has thrown his missal across the room and broken Beatrice's ballet-dancing figurines, the narrator attempts to comfort her mother. The girl reports: "I meant to say I am sorry Papa broke your figurines, but the words that came out were, 'I'm sorry your figurines broke, Mama”" (Adichie 2003: 10). Bruce, echoing Hewett (2005: 86) and Mantel (2004), observes that Kambili "avoids implicating her father” in his own act of violence. At the same time, however, the critic notices that "through this indirect and veiled manner of speech, [Kambili] is able to broach the subject of Eugene’s abusive behaviour” and “acknowledge her mother's status as innocent victim." Kambili's refusal to overtly recognize Eugene's responsibility in the words of sympathy she addresses to her mother is even more outright than Bruce suggests. The differences between the clause Kambili considers saying but does not ("Papa broke your figurines”) and the one she actually articulates (“your figurines broke”) can be clearly highlighted using systemic-functional grammar, and more precisely Halliday and Matthiessen's ergative model of transitivity (2004: 284-95). ${ }^{20}$

The two clauses referring to the breaking of the figurines are material clauses, i.e. clauses that "constru[e] a quantum of change in the flow of events as taking place through some input of energy" (Halliday and Matthiessen 2004: 179). ${ }^{21}$ Using Halliday and Matthiessen's method, the clause patterns can be represented in a table as follows:

\footnotetext{
${ }^{20}$ It is important to clarify here that Halliday and Matthiessen's use of the term "ergative” in functional grammar is different from the one used in formal linguistics. In its traditional sense, an "ergative" is a verb that can be used transitively or intransitively, so that the "object of the verb in its transitive function becomes the subject of the verb in its intransitive function" (Aitchison 1996: 100). Examples illustrating this point would be "Gunfire scattered the crowd" and "The crowd scattered" (Aitchison 1996: 100). Halliday and Matthiessen's "ergative model" is unrelated to this definition, as their theory concerns itself with the identification of the "Medium" through which a "Process" is actualized (note that capital letters are used at the beginning of functions by convention). By way of example, the authors analyze an extract from Noah's Ark in which "'the great flood' serves the same ergative role in I am going to send a great flood and the great flood spread” (2004: 284). In practise, however, the traditional notion of ergativity and Halliday and Matthiessen's theory sometimes overlap, as will indeed be the case here.

${ }^{21}$ These clauses differ from mental clauses, which express "processes of sensing” and are "concerned with our experience of the world of our own consciousness" (2004: 197) and relational clauses, which express "processes of being and having" and "serve to characterize and to identify" (2004: 210). Other process types include behavioural clauses (2004: 248-52), verbal clauses (2004: 252-56) and existential clauses (2004: 256-59).
} 
Published in: Style in African Literature: Essays on Literary Stylistics and Narrative Styles, ed. by J.K.S. Makokha, Ogone John Obiero \& Russell West-Pavlov (Amsterdam \& New York: Rodopi, 2012), pp. 31-57.

Status: Postprint (Author's version)

\begin{tabular}{|l|l|l|l|}
\hline & Agent Process & Medium & \\
\hline Doing & Papa broke & your figurines & \\
\hline Happening & & your figurines & broke \\
\hline & & Medium & Process \\
\hline
\end{tabular}

In both clauses, the verbal group "broke" realizes the function of Process, and the nominal group "your figurines” that of Medium, i.e. the role "through which the process is actualized" (2004: 284). ${ }^{22}$ However, the clauses display a crucial difference in pattern. While "Papa broke your figurines" is a clause of "doing," which is to say that "the actualization of the process is represented as being caused by a participant [the Agent] that is external to the combination of Process + Medium” (2004: 285), “your figurines broke” is a clause of "happening,” meaning that "the process is represented as being self-engendered" (2004: 285). ${ }^{23}$ As Halliday and Matthiessen further point out, the latter structure corresponds to a particular way of representing "reality": "In the real world, there may well have been some external agency involved in [the Process]; but in the semantics of English it is represented as having been selfcaused"(2004: 290, my emphasis). In other words, Kambili's formulation "the figurines broke" not only avoids implicating her father, but also refrains from including any form of agency. By presenting the Process as self-engendered, she even staves off the question "by whom or by what?" that might have been raised had she used the receptive "the figurines got broken” (Halliday and Matthiessen 2004: 290). ${ }^{24}$

Kambili masks the brutality of Eugene's abuse with her words, ${ }^{25}$ and her mother engages in a similar act. When a pregnant Mama is beaten so heavily by her husband that she suffers a miscarriage, on her return from hospital she reports to her children: "There was an accident, the baby is gone" (2003: 34). The existential clause "there is" indicates that "something exists or happens" (Halliday and Matthiessen 2004: 256) - here the use of a material clause, a type of clause that could, in its “doing” form, integrate an Agent, is avoided altogether. In addition, the noun "accident” denotes an absence of deliberate agency. The second part of the sentence, "The baby is gone," follows the same pattern as "the figurines

\footnotetext{
${ }^{22}$ A nominal group in functional grammar corresponds to a noun phrase in formal grammar.

${ }^{23}$ Using traditional terminology, clauses of "doing" are called "transitive" and clauses of "happening" are called "intransitive" (2004: 180).

${ }^{24}$ Halliday and Matthiessen prefer the term "receptive" to the traditional "passive," and the word "operative” to "active" (2004: 181-82).

${ }^{25}$ An analogous point is made by Cooper when she argues that "Words [...] do not say what Kambili means and are instruments of concealment of the reality of Papa's crimes" (2008: 116). However, the critic relates this to the character's lack of control over her utterances: words "involuntar[il]y" come out of Kambili's mouth (2008: 116).
} 
Published in: Style in African Literature: Essays on Literary Stylistics and Narrative Styles, ed. by J.K.S. Makokha, Ogone John Obiero \& Russell West-Pavlov (Amsterdam \& New York: Rodopi, 2012), pp. 31-57.

Status: Postprint (Author's version)

broke” in Halliday and Matthiessen's ergative model, and does not leave any room for an Agent in the Process + Medium structure, either. ${ }^{26}$ As Debra Beilke has observed, the silence around Eugene's implication in these traumatic events suggests that his abuse "not only maims [his family members'] bodies but it also serves to control their tongues” (2006: 2).

Kambili repeatedly deploys indirect, euphemistic tactics to describe her father's acts of violence in the course of the novel. As I have demonstrated elsewhere (Tunca 2009b), the systemic-functional framework can help one to establish that, in a 260-word passage relating the first severe beating received by Kambili, Jaja and their mother at the hands of Eugene, the linguistic makeup of the extract does not once present the Achike father as the direct perpetrator of his brutal act. Instead, the stylistic arrangement of Kambili's report identifies the object used by the man to hit his family, namely his belt, as the true culprit.

This textual subterfuge and the construction found in "your figurines broke" are central to the novel's strategy, for they show how the young narrator's admiration for her father subconsciously affects her account. I believe such a demonstration to be central to the understanding of the book, for it allows one to challenge the consensus reached by reviewers in their appraisal of Kambili's narrative voice: the heroine's tale has consistently been described in terms such as "emotionless" (Okorafor-Mbachu 2004) and "dispassionate" (Ekwe-Ekwe 2005) on account of its apparent leaning towards factuality. Using techniques from systemic-functional grammar, I have tried to show that, on the contrary, the presence of certain grammatical structures reflect the narrator's pronounced emotional bias. ${ }^{27}$

\section{Conclusion}

In the above case study, I have successively used sociolinguistic theory and systemicfunctional grammar in an attempt to establish how different facets of characterization in Adichie's Purple Hibiscus were defined by the protagonists' choice of language on the one hand, and by some of the stylistic features of their speech on the other. By examining the culturally-specific act of codeswitching between Igbo and English and the less strongly context-dependent feature of grammatical agency in a single reading of the novel, I have endeavoured to show that the linguistic complexity of this particular African book could be

\footnotetext{
${ }^{26}$ That Mama's unborn baby is labelled the "Medium" is independent of the ethical debate around the conception of a foetus as an "unborn person" or a mere "organism." The examples of Medium + Process structures provided by Halliday and Matthiessen include "the glass broke," "the baby sat up" and "the boy ran" (2004: 290), which clearly indicates that the term "Medium" can be applied to both objects and people.

${ }^{27}$ Interestingly, this strategy and similar forms of prejudice encoded in the language recede as the heroine becomes emancipated from her father. See Tunca (2009a; 2009b).
} 
Published in: Style in African Literature: Essays on Literary Stylistics and Narrative Styles, ed. by J.K.S. Makokha, Ogone John Obiero \& Russell West-Pavlov (Amsterdam \& New York: Rodopi, 2012), pp. 31-57.

Status: Postprint (Author's version)

unveiled only if the text was approached from several complementary angles.

Admittedly, the above analysis is still considerably removed from an examination that would provide an actual stylistic "model” for the study of Anglophone African literatures. Such an achievement would require several more years of research. Nevertheless, I believe that the outline given here could potentially be developed into a comprehensive analytical paradigm, provided that due attention is directed to three points: firstly, the theoretical referents used in this case study need to be supplemented by a number of others, so as to accommodate genres such as poetry and drama, and to be applicable to the various literary traditions of Anglophone Africa. Such broadening of scope would also require a move beyond an exclusively character-based methodology - one should, in other words, not lose sight of the impact of the author's style of writing on the interpretation of a literary piece. Secondly, the culturally-specific and context-independent approaches adopted above need to be made to interact more closely, so as to avoid the reproduction, within single analyses, of the epistemological dichotomy perpetuated in linguistic studies of African literatures over the decades. Attaining this second goal would entail significant methodological research, as would the third improvement to be made, namely that all insight gained through systemicfunctional techniques should be scrutinized through an additional cognitive lens. The challenge, once again, resides in combining these approaches rather than merely superposing them. While much work remains to be done in the particular area of "functional cognitive stylistics,” preliminary research has suggested that such a synthesis might lead to fruitful new applications in the domain of textual analysis (see Croft 2009; Stockwell 2000).

In sum, even if many questions remain unanswered at this stage, I hope that this article has raised stylistic critics' awareness of the challenges currently facing them. To attempt to achieve this goal, I started by looking at the past, providing a short history of the language debate and a critical examination of its impact on the linguistic analysis of Anglophone African literatures. Identifying the factors that may have hindered progress in the field of “African stylistics” is, I believe, the first step towards overcoming the obstacles that lie ahead. ${ }^{28}$ The second part of this essay has also tried to pave the way for future developments. My analysis of Purple Hibiscus was designed to demonstrate the role of linguistic theory in giving a literary interpretation of the novel but also, and above all, to convince stylistic critics

\footnotetext{
${ }^{28}$ Among these obstacles, I include methodological confinement in general. Indeed, I anticipate that the epistemological crisis faced by African literary-linguistic criticism in the twentieth century will resurface in reversed form as the third millennium progresses, for some commentators might question the applicability of culturally-specific approaches to the works of African writers when these authors live in the diaspora. While such sensitive issues deserve to be examined with care, one should be cautious not to let the debate reach a critical impasse.
} 
Published in: Style in African Literature: Essays on Literary Stylistics and Narrative Styles, ed. by J.K.S. Makokha, Ogone John Obiero \& Russell West-Pavlov (Amsterdam \& New York: Rodopi, 2012), pp. 31-57.

Status: Postprint (Author's version)

of the need to continue to sharpen their methodological tools.

\section{References}

Achebe, C. (1975/1965) “The African Writer and the English Language.” Morning Yet on Creation Day: Essays. London: Heinemann. 55-62.

Adeaga, T. (2005) "Style and Other Impediments in Chimamanda Ngozi Adichie’s Purple Hibiscus.” Paper presented at Beyond the Printed Word: African Literatures, African Cultures. African Literature Association Conference, Boulder, USA.

Adegbija, E. (1998) “Toward a Speech-Act Approach to Nigerian Literature in English.” In E.L. Epstein, R. Kole (eds) The Language of African Literature. Trenton: Africa World Press. 41-56.

Adejare, O. (1992) Language and Style in Soyinka: A Systemic Textlinguistic Study of a Literary Idiolect. Ibadan: Heinemann.

Adichie, C. N. (2003) Purple Hibiscus. Chapel Hill: Algonquin Books of Chapel Hill.

Aitchison, J. (1996) Cassell's Dictionary of English Grammar. London: Cassell.

Akekue, D. (1992) “Mind-Style in Sozaboy: A Functional Approach to Language.” In C. Nnolim (ed) Critical Essays on Ken Saro-Wiwa's Sozaboy: A Novel in Rotten English. London: Saros. 16-29.

Armah, A.K. (1977/1976) "Larsony or Fiction as Criticism of Fiction.” In New Classic 4, 3345.

Bamiro, E. (2006) “Nativization Strategies: Nigerianisms at the Intersection of Ideology and Genre in Achebe’s Fiction.” World Englishes 25, 315-328.

Beilke, D. (2006) “'Blue Tongues of Fire': Suppressing the Mother('s) Tongue in Chimamanda Ngozi Adichie's Purple Hibiscus.” Presented at Pan-Africanism in the $21^{\text {st }}$ Century: Generations in Creative Dialogue. African Literature Association Conference. Accra, Ghana.

Bennett, L. (1986/1966) “Colonization in Reverse.” In P. Burnett (ed.) The Penguin Book of Caribbean Verse in English. Harmondsworth: Penguin. 32-33.

Bhabha, H. K. (1994) “Of Mimicry and Man: The Ambivalence of Colonial Discourse.” The Location of Culture. London: Routledge. 85-92.

Braunstein, E. (2005) Out of Africa. Salient, 4. [Web Page] Retrieved 23 Jun 2007 from http://www.salient.co.nz.

Bruce, K. (n.d.) Listening to the Silences: Women's Silence as a Form of Oppression and a 
Published in: Style in African Literature: Essays on Literary Stylistics and Narrative Styles, ed. by J.K.S. Makokha, Ogone John Obiero \& Russell West-Pavlov (Amsterdam \& New York: Rodopi, 2012), pp. 31-57.

Status: Postprint (Author's version)

Mode of Resistance in Chinamanda [sic] Ngozi Adichie’s Purple Hibiscus. [Web Page] Retrieved 20 Oct 2007 from http://www.textualchemy.net/listening\%20to\%20 silences.doc.

Chinweizu, O. J., \& Ihechukwu, M. (1983) Toward the Decolonization of African Literature.

Vol. 1. Washington: Howard University Press.

Cooper, B. (2008) “Breaking Gods and Petals of Purple in Chimamanda Ngozi Adichie’s

Purple Hibiscus.” In A New Generation of African Writers: Migration, Material Culture and Language. London: James Currey. 110-132.

Croft, W. (2009) “Toward a Social Cognitive Linguistics.” In V. Evans, S. Pourcel (eds) New Directions in Cognitive Linguistics. Amsterdam: John Benjamins. 395-420.

Ekwe-Ekwe, H. (2005) “Chimamanda Ngozi Adichie.” Literary Encyclopedia. [Web Page] Retrieved 21 Oct 2009 from http://www.litencyc.com/php/speople.php?rec=true\&UID $=6014$.

Epstein, E.L., Kole, R. (eds) (1998) The Language of African Literature. Trenton: Africa World Press.

Essien, A. (2000) "Discourse Analysis and Characterization in the Novel." In E. N. Emenyonu (ed) Goatskin Bags and Wisdom: New Critical Perspectives on African Literature. Trenton: Africa World Press. 51-63.

Fish, S. E. (1996/1980) "What Is Stylistics and Why Are They Saying Such Terrible Things about It?” In J.-J. Weber (ed) The Stylistics Reader: From Roman Jakobson to the Present. London: Arnold. 94-116.

Fowler, R. (1996/1986) Linguistic Criticism. Oxford: Oxford University Press.

Gates, H. L. Jr. (1984) “Criticism in the Jungle.” In H. L. Gates Jr (ed) Black Literature and Literary Theory. New York: Methuen. 1-24.

Griffiths, G. (1971) “Language and Action in the Novels of Chinua Achebe.” African Literature Today 5, 88-105.

Griswold, W. (2000) Bearing Witness: Readers, Writers and the Novel in Nigeria. Princeton: Princeton University Press.

Halliday, MA. K., C. M. I. M. Matthiessen. (2004) An Introduction to Functional Grammar. $3^{\text {rd }}$ ed. London: Hodder.

Hewett, H. (2005) “Coming of Age: Chimamanda Ngozi Adichie and the Voice of the Third Generation.” English in Africa 32, 73-97.

Igboanusi, H. (2001) "Varieties of Nigerian English: Igbo English in Nigerian Literature.” Multilingua 20, 361-78. 
Published in: Style in African Literature: Essays on Literary Stylistics and Narrative Styles, ed. by J.K.S. Makokha, Ogone John Obiero \& Russell West-Pavlov (Amsterdam \& New York: Rodopi, 2012), pp. 31-57.

Status: Postprint (Author's version)

Kanneh, K. (1997) "What is African Literature? Ethnography and Criticism.” In M.-H. Msiska, P. Hyland (eds) Writing and Africa. London: Longman. 69-86.

Kaplan, E. A. (2004) “Cry, Freedom. Rev. of Purple Hibiscus, by C.N. Adichie.” LA Weekly. [Web Page] Retrieved 20 Oct 2007 from http://www.laweekly.com/art+books/wls/cryfreedom/13671.

Lakoff, G. (1987) Women, Fire, and Dangerous Things: What Categories Reveal about the Mind. Chicago: Chicago University Press.

— Johnson, M. (1980) Metaphors We Live By. Chicago: University of Chicago Press.

—, Turner, M. (1989) More Than Cool Reason: A Field Guide to Poetic Metaphor. Chicago: University of Chicago Press.

Lalami, L. (2003) Chimamanda Ngozi-Adichie's [sic] Purple Hibiscus. [Web Page] Retrieved 21 Oct 2009 from http://ailalalami.com/2003/Chimamanda-ngozi-adichiespurplehibiscus/\#000674

Lanham, R. A. (2003) Analyzing Prose. $2^{\text {nd }}$ ed. London: Continuum.

Leech, G., Short, M. (2007/1981) Style in Fiction: A Linguistic Introduction to English Fictional Prose. London: Longman / Harlow: Pearson.

Lopez, M. S. (2008) “Creating Daughterlands: Dangarembga, Adichie, and Vera.” JALA 2.1, 83-97.

Mantel, H. (2004) “I Have Washed My Feet out of It. Rev. of Purple Hibiscus, by C.N. Adichie.” London Review of Books 26.20. [Web Page] Retrieved 21 Oct 2009 from http://www.lrb.co.uk/v26/n20/mant01_html.

Moore, G. (1997/1963) “Reply to 'The Dead End of African Literature.”” Transition 75/76, 339-40.

Mphahlele, E. (1997/1963) "Reply to 'The Dead End of African Literature.”'Transition 75/76, 336-39.

Myers-Scotton, C. (1993) Social Motivations for Codeswitching: Evidence from Africa. Oxford: Oxford University Press.

Ngara, E. (1982) Stylistic Criticism and the African Novel. London: Heinemann.

—, (1990) Ideology and Form in African Poetry:Implications for Communication. London: James Currey.

Ngugi wa Thiong'o (1986) Decolonising the Mind: The Politics of Language in African Literature. London: James Currey.

Nnolim, C. E. (2000) “Trends in the Criticism of African Literature.” In E. N. Emenyonu (ed) Goatskin Bags and Wisdom: New Critical Perspectives on African Literature. Trenton: 
Published in: Style in African Literature: Essays on Literary Stylistics and Narrative Styles, ed. by J.K.S. Makokha, Ogone John Obiero \& Russell West-Pavlov (Amsterdam \& New York: Rodopi, 2012), pp. 31-57.

Status: Postprint (Author's version)

Africa World Press. 3-15.

Obiechina, E. (1993) “Narrative Proverbs in the African Novel.” Research in African Literatures 24.4, 123-40.

Okorafor-Mbachu, N. (2004) “Rev. of Purple Hibiscus, by Chimamanda Ngozi Adichie.” Other Voices 40. [Web Page] Retrieved 21 Oct 2009 from http://www.webdelsol.corn/Other_Voices/Reviews40.htm.

The Oxford English Dictionary. Oxford: Oxford University Press. [Web Page] Retrieved 21 Oct 2009 from http://www.oed.com.

Osundare, N. (2002) Thread in the Loom: Essays on African Literature and Culture. Trenton: Africa World Press.

Semino, E., \& Culpeper, J. (2002) Cognitive Stylistics: Language and Cognition in Text Analysis. Amsterdam: John Benjamins.

Simpson, P. (1997) Language through Literature: An Introduction. London: Routledge.

—, (2004) Stylistics: A Resource Book for Students. London: Routledge.

Soyinka, W. (1997/1963) “Reply to 'The Dead End of African Literature.”” Transition 75/76, 340.

Stockwell, P. (2002) Cognitive Poetics: An Introduction. London: Routledge.

__, (2000) “Towards a Critical Cognitive Linguistics?” In I. Biermann, A. Combrink (eds) Poetics, Linguistics and History: Discourses of War and Conflict. Potchefstroom: Potchefstroom University Press. 510-528.

Tunca, D. (2008) Style beyond Borders: Language in Recent Nigerian Fiction. PhD Dissertation. University of Liege.

—_, (2009a) “Ideology in Chimamanda Ngozi Adichie’s Purple Hibiscus” (2003). English Text Construction 2.1, 121-131.

—, (2009b) “An Ambiguous 'Freedom Song': Mind-Style in Chimamanda Ngozi Adichie’s Purple Hibiscus”. Postcolonial Text 5.1, 1-18. [Web Page] Retrieved 25 Jan 2010 from http://journals.sfu.ca/pocol/index.php/pct/article/view/925/93.

__, (forthcoming) "Of French Fries and Cookies: Chimamanda Ngozi Adichie’s Diasporic Fiction.” In K. Gyssels, B. Ledent (eds) Presence africaine en Europe / African Presence in Europe. Paris: L'Harmattan.

Verdonk, P. (2002) Stylistics. Oxford: Oxford University Press.

Wales, K. (2006) “Stylistics.” In K. Brown (ed), Encyclopedia of Language and Linguistics $2^{\text {nd }}$ ed. Vol. 12. Oxford: Elsevier. 213-217

Wali, O. (1997/1963) “The Dead End of African Literature.” Transition 15116, 330-35. 
Published in: Style in African Literature: Essays on Literary Stylistics and Narrative Styles, ed. by J.K.S. Makokha, Ogone John Obiero \& Russell West-Pavlov (Amsterdam \& New York: Rodopi, 2012), pp. 31-57.

Status: Postprint (Author's version)

Winters, M. (1981) “An Objective Approach to Achebe's Style.” Research in African Literatures 12.1, 55-68.

Zabus, C. (2007/1991) The African Palimpsest: Indigenization of Language in the West African Europhone Novel. Amsterdam: Rodopi. 